\title{
Has Leprosy Tendency to Spontaneous Arrest Without Defect ?
}

\author{
P. H. J. Lampe.
}

(Reprinted from "Het Geneeskundig Tijdschrift voor Nederlandsch Indie," afl. 15 Deel 72, 1932, pp. 946-952).

\section{INTRODUCTION.}

QURINAM is favourably situated for the study of the - epidemiology of leprosy and related problems. The limited population $(150,000)$ of the inhabited area is under good medical supervision and a fairly successful registration of the population in town and districts permits many investigations of a medico-statistical nature, which up to now were quite impossible in tropical countries with endemic leprosy.

The most reliable and most complete figures which can be gathered from the native population (negroes and coloured people) shows that not less than 60 per cent. of that population of 60,000 souls live in the capital, Paramaribo. Other advantages are that on account of the fact that there is little or no emigration or immigration, the differentiation of sex and age-groups of the native population vary little from year to year and on account of this imperceptible growth, this remains almost stationary.

TABLB I.

The Nungar of Known Cases of Leprosy, Difzkrentiatid in Races AND AgE-Grouts.

\begin{tabular}{|c|c|c|c|c|c|}
\hline $\begin{array}{c}\text { Age- } \\
\text { Groops. }\end{array}$ & $\begin{array}{c}\text { Negroes and } \\
\text { Coloured } \\
\text { People. }\end{array}$ & $\begin{array}{l}\text { British } \\
\text { Indians. }\end{array}$ & $\begin{array}{c}\text { Netherland } \\
\text { East } \\
\text { Indians. }\end{array}$ & Others. & Total. \\
\hline $\begin{array}{ll}0-4 & \cdots \\
5-9 & \cdots \\
10-14 & \cdots \\
15-19 & \cdots \\
20-29 & \cdots \\
30-99 & \cdots \\
40-49 & \cdots \\
50-64 & \cdots \\
65- & \cdots \\
\text { Unknown }\end{array}$ & $\begin{array}{r}15 \\
108 \\
160 \\
158 \\
177 \\
112 \\
76 \\
45 \\
13 \\
12\end{array}$ & $\begin{array}{r}\overline{10} \\
11 \\
13 \\
21 \\
30 \\
49 \\
46 \\
5 \\
18\end{array}$ & $\begin{array}{l}-5 \\
3 \\
1 \\
1 \\
2 \\
7 \\
2 \\
2\end{array}$ & $\begin{array}{l}\overline{-} \\
\overline{1} \\
2 \\
\frac{1}{1} \\
2 \\
2 \\
2\end{array}$ & \begin{tabular}{r|}
15 \\
123 \\
174 \\
173 \\
201 \\
144 \\
133 \\
95 \\
20 \\
34
\end{tabular} \\
\hline Total . . & 876 & 203 & 23 & 10 & 1,112 \\
\hline
\end{tabular}


The result of an anti-leprosy campaign inaugurated in 1927 has been that, without exaggeration, it can be said that the estimated number of known cases of leprosy is very nearly the same as the number of those known to be suffering from clinical leprosy.

Surinam is one of the few countries with endemic leprosy in high degree, where the differentiation of cases in age-groups can be studied. It is also one of the few countries where a remarkable peculiarity of that differentiation is seen ; this, in my opinion, is important enough to warrant attention.

TABle II.

The Number of Sutperers prom "Clinical" Leprosy of the Native Population of Surinam PER 1,000 of Each Age-Group : (MorbidityINDICES.)

\begin{tabular}{|c|c|}
\hline Age-Groups. & Morbidity-Indices. \\
\hline $0-4$ & $1 \cdot 9$ \\
$5-9$ & $16 \cdot 6$ \\
$10-14$ & $24 \cdot 6$ \\
$15-19$ & $25 \cdot 9$ \\
$20-29$ & $19 \cdot 2$ \\
$30-39$ & $13 \cdot 2$ \\
$40-49$ & $11 \cdot 7$ \\
$50-64$ & $7 \cdot 9$ \\
$65-$ & $4 \cdot 6$ \\
Average & $14 \cdot 7$ \\
\hline
\end{tabular}

TABle III.

Ratio of Morbidity-Indices (TABle II); LARgest INDEX $=100$.

\begin{tabular}{|c|c|c|}
\hline Age-Groups. & $\begin{array}{c}\text { Morbidity-Indices } \\
\text { (comparing-figures). }\end{array}$ & $\begin{array}{c}\text { Morbidity- } \\
\text { Decrease. }\end{array}$ \\
\hline $0-4$ & & Per cent. \\
$5-9$ & 7 & \\
$10-14$ & 64 & \\
$15--19$ & 95 & 26 \\
$20-29$ & 700 & 31 \\
$30-39$ & 51 & 12 \\
$40-49$ & 45 & 13 \\
$50-64$ & 31 & 42 \\
$65-$ & 18 & \\
\hline
\end{tabular}

Considerations.

It is important to note the relations of the morbidityrates, stated in Tables II and III, namely the increase of the 
morbidity in proportion to the age until the age of 15 to 19 years is reached, and the decrease of the morbidity in proportion after the age of 20 years.

It is shown in the above that up to 20 years the chances of contracting leprosy are increased.

The decrease of that chance after the age of 20 years is reached, is difficult to understand, as the contrary should be expected or, at least, a less marked decrease, as leprosy is generally believed to be a disease which can develop at any age and is a chronic disease with little mortality.

In theory, the following factors can be considered as responsible for the rapid decrease of morbidity aftertwenty.

(a) The diagnosis is wrong in many cases of the younger age-groups.

(b) The large number of young cases of leprosy is a recent appearance.

(c) The knowledge about cases older than 20 years of age is less complete.

(d) The mortality of cases of leprosy is very large.

(e) Many young cases cannot be recognised as such later in life.

(a) Almost all diagnoses are stated or controlled by an official leprosy board of five medical men with much experience in leprosy, both clinical and bacteriological. That the decrease of the morbidity should be the result wholly or partly, of a large number of wrong diagnoses in the younger age-groups is hardly likely.

(b) Though I am inclined to believe that in Surinam the first visible symptoms of leprosy as a rule develop during youth, so that in my opinion an increase of leprosy will manifest itself firstly in an increase of the morbidity of the younger age-groups, yet I hesitate to consider that possibility as the cause of the high morbidity in these age-groups. Leprosy in Surinam is principally a disease of the native population and for that reason a town disease. On the one hand, the native population of the town is increasing without proportional extension of the dwelling space; on the other hand, better ideas about hygiene in general and about the prevention of leprosy in particular arise, whereas, the economic conditions of those classes of the population where leprosy prevails, have not changed to any remarkable degree.

For the above reasons I cannot believe that the relative high morbidity in the younger age-groups is due to an increase of leprosy, which increase would manifest itself 
later on in a proportional increase of the morbidity indices of all other age-groups. If this occurred, the incidence of leprosy in Surinam would be almost doubled.

(c) As mentioned in the introduction, the number of known cases of leprosy (natives) is not far behind the real number of clinical cases and, therefore, allows careful conclusions in regard to certain statistical calculations. Nevertheless, it is not impossible that the knowledge about the occurrence of leprosy among school children and young adults who, in their school period, were under regular medical supervision, is more complete than that of the older age-groups, who, in their school period were not regularly examined for leprosy, unless the early symptoms of leprosy, which as a rule develop in youth on parts of the body covered by clothing remain the same without arousing any serious suspicion among the sufferers or their close relations.

(d) The figures which are at my disposal suggest that in Surinam, the mortality rate of sufferers from leprosy is an important point, and is greater than the rate of those not afflicted within the age-group of 15 to 19 years, but not to such a degree that the rapid decrease of morbidity after this age can be attributed to the larger number of cases dying before the age of 30 is reached.

N.B.-The highest morbidity of advanced cutaneous types of leprosy is found in Surinam among men from 15 to 19 years and women from 20 to 29 years.

That the higher mortality of leprosy is not the main reason, neither a reason of any importance for the decrease of morbidity, is proved by the fact that the same decrease of morbidity is found in the neural types of leprosy without the possibility of tracing the lost cases as changed in cutaneous cases.

(e) The only remaining factor which theoretically can be considered as responsible for the large decrease of the morbidity is that a number of young cases cannot be recognised as suffering from leprosy when they are older, and do not consider themselves as cases of leprosy.

\section{CoNClusion.}

The above considerations lead to the hypothesis that in many cases the early symptoms of leprosy in children and young adults remain the same or diminish ; in other words, only some of the externally visible lesions of leprosy develop into the more advanced stages which, in countries with endemic leprosy, are recognised by laymen. It is in that sense that the title of this paper is to be read. 


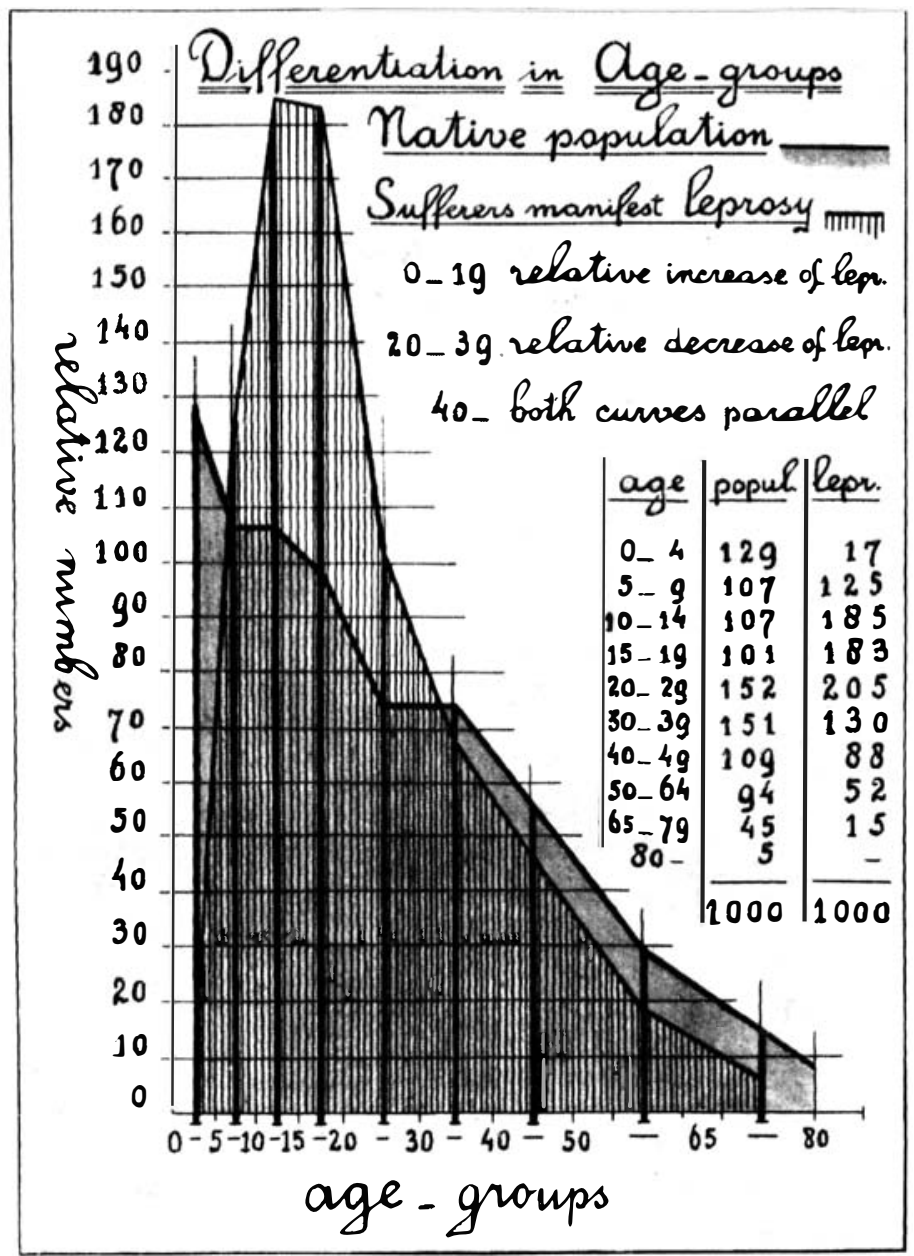




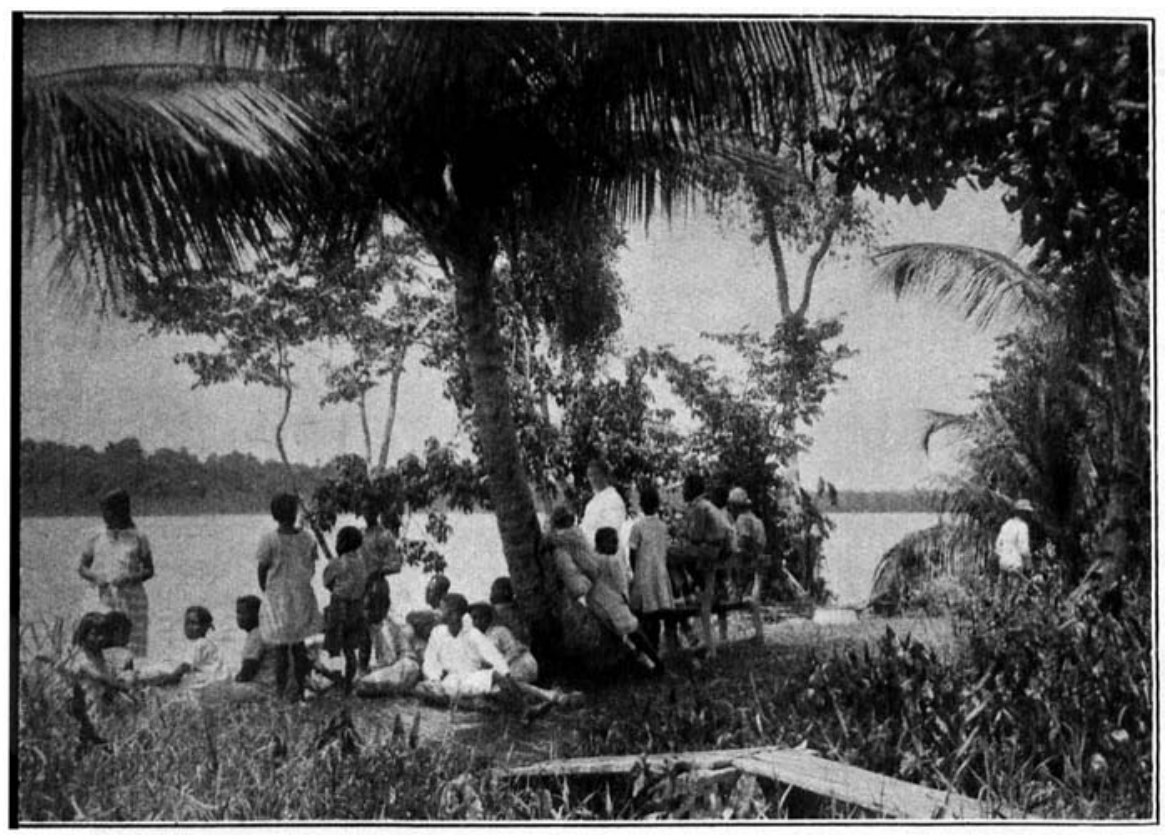

II Leprosy Asylun “ Bethesida."

A Corner of the Playground.

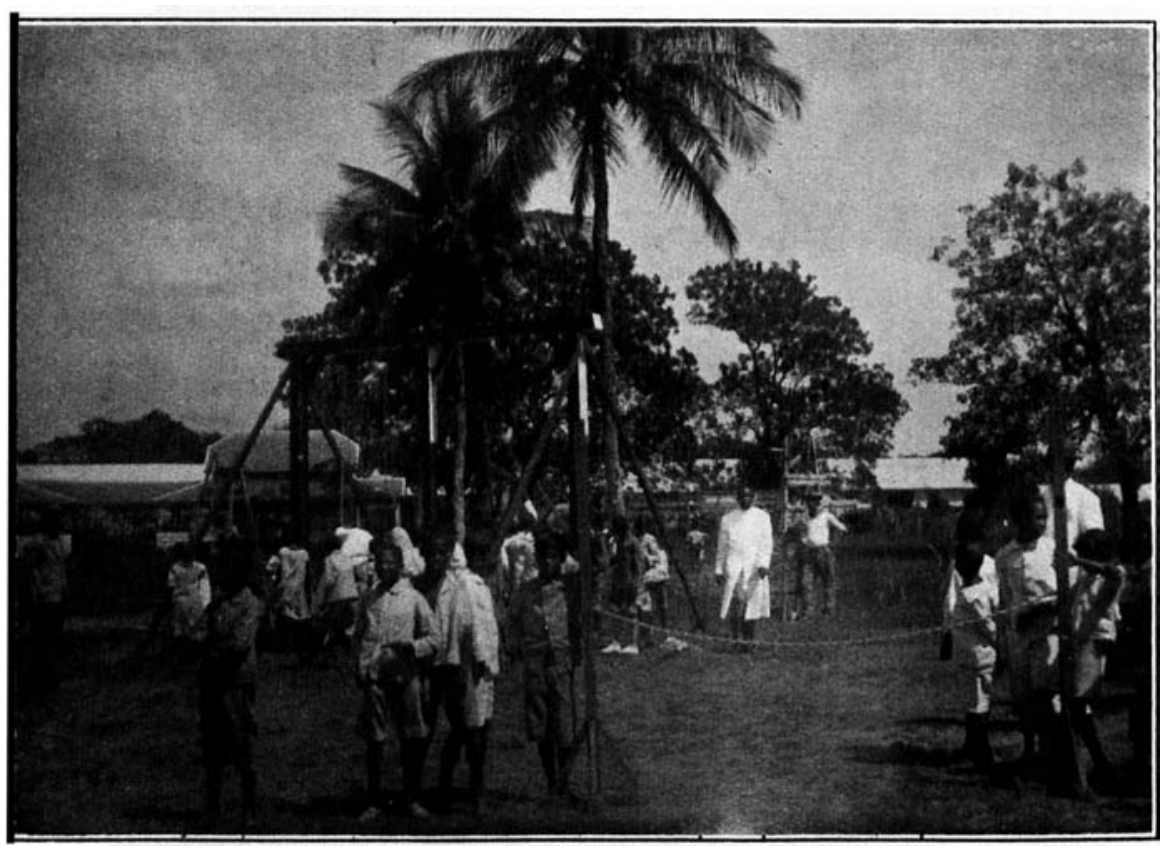

IV. Disprensary selhoul.

Plavground of the school. 
Probably the same hypothesis.applies to early symptoms which develop at a later age, but the figures to hand cannot give conclusions about that.

$N . B$.- It is not only improbable, but rather impossible, that those frequent arrests without defects are the results of (specific) therapeutic measures, as the application of same in Surinam on a large scale is of too recent date.

The conclusion discussed above is confirmed by my own clinical observations. Spontaneous arrest of visible symptoms indicating active leprosy infection-already described by Hansen-is known to all clinicians (Reference Nos. 3, 8, 12 and others).

Spontaneous arrest of " early " symptoms is also observed by others and by some authors its frequent occurrence is emphasised (Reference Nos. $1,4,5,6,7,11$ ).

Further, there are observers who, doubting the therapeutic value of the so-called specific medical treatment, impute the good results of the modern leprosy treatment to the tendency of leprosy to regress spontaneously (Reference No. 14).

Finally, reference can be made, be it with some hesitation, to a few epidemiological facts, which are better understood if " subliminal infections" or " abortive cases" are frequently met with, and antibodies are formed (Reference Nos. 1 to 5, 7, 12 and others).

For example :-

(a) The often mysterious insusceptibility of persons in infected surroundings, who so far as is known have to be considered as susceptible.

(b) The less frequent occurrence of conjugal leprosy (in countries with endemic leprosy).

(c) The proportionally more frequent occurrence of early leprosy at an older age among people who have spent their youth in leprosy-free countries (personal impressions).

(d) The fact that in some cases their infection cannot be traced in spite of every investigation.

Finally, in the above suggestion the frequent occurrence of the " abortive." type of leprosy is further illustrated by epidemological observations in connection with the other chronic infectious diseases, viz., the tuberculosis (Reference No. 13 and others).

\section{REFERENCES.}

'Bargehr, P. Spezifische Hautreaktion bei Lepra. Zeitchrift, f. Imm. und Exp. Ther. 1926, June 28th. Vol. XLVII, Nr. 6, pp. 529-531. 
'Bargehr, P. Künstliche lepraspezifische Allergie und aktive Immunisierung gegen Lepra. As above, 1926. December 6th. Vol. XLIX, Nr. 3-4, pp. 346-353.

- Bergehr, P. Die selbstheilung der Lepra. Geneesk. Tijdschrift v. Ned. Indie, 1926. Vol. LXVI, Nr. 5, pp. 603-609. Münsch. Med. Wochenschr. 1926. Dec. 24th. Vol. LXXIII, Nr. 52, pp. 2209-2210.

'Bargehr, P. Abortiv verlauf ende Lepraerkrankungen. Arch. f. Derm. u. Syph. 1927. July 4th. Vol. CI III, Nr. 2, pp. 295-299.

'Cochrane, R. G. Leprosy, its prevention and control. The Journal of State Medicine. Vol. XXXIX, Nr. 10.

-Gougerot, H. Les formes atténuées localisées, finées curables de la Lepre. Ref. Trop. Dis. Bull. 1928. August. Vol. XXV, Nr. 8, p. 641.

${ }^{7}$ Hoffmann, W. H. Ueber latente Immunisierungsvorgänge bei der Lepra. Zeitschr.f. Imm. u. Exp. Ther. 1929. Vol. LIX, Nr. 3-4, pp. 297-303.

'Hopkins, R. Leprosy with special reference to self-limiting phases of the disease. Ref. Trop. Dis. Bulletin, 1927. March. Vol. XXIV, Nr. 3, blz. 211 .

${ }^{\circ}$ De Langen, C. D. Gen. Tijdschr. v. Ned. Indië. Vol. LXXI, Part 4. April 1st, 1931. p. 391.

${ }^{10}$ Leonard Wood Memorial Conference. The Philippine Journal of Science. Vol. XLIV, Nr. 4. April, 1931. pp. 449-480.

${ }^{11}$ De Mello. Ref. Trop. Dis. Bull. 1929. December. Vol. XXVI, Nr. 12, p. 1032.

${ }^{12}$ Muir, E. Leprosy a self healing disease. Lancet, 1924. Feb. 9th. pp. 277-280.

1sRogers, R. Resemblances between leprosy and tuberculosis. Brit. Jl. Tuberculosis, 1925. April. Vol. XIX, Nr. 2, pp. 69-73.

"Wayson, N. E. Observation on the treatment of leprosy in Hawaii. Public Health Reports, 1929. Dec. 20th. Vol. XLIV, Nr. 51, pp. 3095-3110. 